\title{
Protein malnutrition in the rat induced by protein-calorie imbalance
}

\author{
By T. W. WIKRAMANAYAKE* \\ Faculty of Medicine, Colombo 8, Ceylon \\ (Received 28 March I966-Accepted 26 April r966)
}

\begin{abstract}
I. A study has been made of the effect of feeding growing rats for a long time on a lowprotein, high-carbohydrate diet given at two different levels of energy. 2. When the proteins of the diet provided o or $5 \%$ of the calories the body-weight fell rapidly and fat accumulated in the liver. Addition of carbohydrate (glucose) to the diets increased the amount of fat in the liver. 3. It is suggested that a deficiency of protein retards the synthesis in the liver of lipoproteins required for removal of triglyceride from the liver. Additional carbohydrate diverts amino acids from the amino acid pool to tissues such as muscles, increasing the liver damage.
\end{abstract}

It is generally agreed that kwashiorkor is associated with diets which, though low in protein, often provide a relative abundance of carbohydrate. On the other hand, the child with marasmus, in which protein deficiency is associated with an equally severe calorie deficiency, does not develop the stigmata of kwashiorkor (Scrimshaw \& Behar, 1959). Heard, Platt \& Stewart (1958) have shown that baby pigs fed on a lowprotein diet will develop a condition resembling kwashiorkor if additional carbohydrate is added to the diet.

An attempt has been made to produce a similar condition in the rat. Young rats have been maintained for several weeks on synthetic diets in which the protein content was adjusted to give 0,5 and $43 \%$ of calories as casein and the calorie intake adjusted by addition or withdrawal of glucose. The livers of animals were then analysed for their lipid content. A preliminary account of these experiments has already appeared (Wikramanayake, 1964).

\section{EXPERIMENTAL}

\section{Animals and diets}

Young adult albino rats having an initial body-weight close to $\mathrm{I} 60 \mathrm{~g}$ were studied at different levels of energy intake on diets either containing protein or free of protein. The method of selection of the animals, the constituents of the diet, the feeding and the general management of the animals were essentially the same as those employed in earlier experiments (Munro, Naismith \& Wikramanayake, I953; Munro $\&$ Wikramanayake, I954). The details of the diets are given in Table I. To the $2 \mathrm{~g}$ of the vitamin-mineral-roughage (VMR) mixture (Munro, 1949) given to all the animals in the morning, additional choline was added to ensure a daily intake of $40 \mathrm{mg}$ choline.

* Present address: Faculty of Medicine, University of Ceylon, Peradeniya, Ceylon. 
During the first 7 days the daily energy intake of all animals was about $1300 \mathrm{kcal} / \mathrm{m}^{2}$ in order that they might become accustomed to the diet. The surface area was calculated by the method of Lee (1929). At the end of this period the energy intake of the different animals was altered by increasing or reducing the amount of glucose given in the morning meal. The amount of carbohydrate given in the evening meal was sufficient to ensure optimal utilization of dietary nitrogen (Munro, 1949). The additional glucose given separately from this meal would exert an effect on protein metabolism irrespective of the time at which it was given (Munro \& Wikramanayake, 1954).

Table $\mathrm{x}$. Composition of diets given to the rats

\begin{tabular}{|c|c|c|c|c|c|c|c|c|}
\hline \multirow[b]{2}{*}{ Diet } & \multicolumn{2}{|c|}{ Given at 9 am } & \multicolumn{4}{|c|}{ Given at $4 \mathrm{pm}$} & \multirow[b]{2}{*}{$\begin{array}{c}\text { Total } \\
\text { N/day } \\
\text { (mg) }\end{array}$} & \multirow{2}{*}{$\begin{array}{c}\text { Total } \\
\text { calories } \\
\text { per day } \\
\left(\mathrm{kcal} / \mathrm{m}^{2}\right)\end{array}$} \\
\hline & $\begin{array}{l}\text { VMR* } \\
\text { (g) }\end{array}$ & $\underset{\begin{array}{c}\text { Glucose } \\
(\mathrm{g})\end{array}}{ }$ & $\begin{array}{l}\text { Fat } \\
(\mathrm{g})\end{array}$ & $\begin{array}{l}\text { Potato } \\
\text { starch } \\
\text { (g) }\end{array}$ & $\begin{array}{l}\text { Glucose } \\
\text { (g) }\end{array}$ & $\begin{array}{c}\text { Casein } \\
(\mathrm{g})\end{array}$ & & \\
\hline Protein-free & $2 \cdot 0$ & 3.5 & 0.42 & $\mathrm{I} \cdot 89$ & $\mathrm{I} \cdot 89$ & - & $2 \cdot 5$ & $\mathrm{I} 342$ \\
\hline Low-protein & $2 \cdot 0$ & 3.5 & 0.42 & $2 \cdot 79$ & 0.69 & 0.30 & $41 \cdot 0$ & 1352 \\
\hline High-protein & $2 \cdot 0$ & 3.5 & 0.42 & 0.69 & 0.69 & 240 & 330.0 & 1353 \\
\hline
\end{tabular}

In the first experiment, eighteen rats were used, three in each group. Those on the protein-deficient diets lost weight rapidly. By the 5 oth day they were considerably emaciated, took no interest in their surroundings and had to be coaxed to eat the food given them. All the food was not consumed. The animals receiving the protein-free and the low-protein diets at the lower energy level died mainly between the 58 th and $64^{\text {th }}$ days although the last rat died on the $75^{\text {th }}$ day. After death a portion of the liver of each animal was removed for histological examination (haematoxylin and eosin staining of paraffin sections) and the remainder weighed. A portion of the gastrocnemius muscle and the remainder of the carcass were dried at $110^{\circ}$ to a constant weight and the water content was calculated.

In the second experiment, precautions were taken to ensure that all the food was consumed. The evening meal was left in the cage throughout the night. Any food remaining in the dish the following morning was mixed with the VMR mixture, suspended in water and given by stomach tube. The glucose given to those rats fed at the higher energy level was dissolved in the same water. In this way the animals were forced to consume all the food offered to them without, at the same time, disrupting their normal nocturnal constant-feeding habit (Cohn \& Joseph, 1959). On the 56th day of the experiment, i.e. after the animals had been fed at different energy levels for 7 weeks, blood was drawn from each by cardiac puncture under ether anaesthesia about $\mathrm{I} h$ after the animals had been tube-fed. Their livers were perfused with $0.9 \%(\mathrm{w} / \mathrm{v}) \mathrm{NaCl}$, weighed and frozen at $-10^{\circ}$ and later analysed for total lipids, total cholesterol and lipid phosphorus. 


\section{Analytical procedures}

The food was analysed for nitrogen and the serum for total proteins by the microKjeldahl method, with metallic mercury as the catalyst.

Liver lipids were extracted by the method described previously (Wikramanayake, Munro, Naismith \& Hutchison, 1953). The total phosphorus content of a sample of the combined extracts was measured by the method of Allen (1940). Another portion of the lipid extract was dried in an atmosphere of $\mathrm{N}_{2}$ under reduced pressure. The residue was dissolved in light petroleum (b.p. $40^{\circ}-60^{\circ}$ ), dried in a tared vessel and weighed, to obtain a measure of the concentration of the total lipids in the extract. Total cholesterol was estimated on a sample of the extract by the method of Henly (1957). An estimate of the triglyceride content of each liver was obtained by subtracting from the amount of total lipids the sum of the total cholesterol and the total phospholipids (obtained by multiplying the value for phospholipid phosphorus by 25).

Equal volumes of blood serum from animals in the same group were pooled and the pooled samples analysed for total lipids, total cholesterol, phospholipid phosphorus and total proteins, and the serum proteins fractionated by paper electrophoresis. Cholesterol was determined directly in the serum proteins by Henly's (1957) method. Total lipids were extracted from $2 \mathrm{ml}$ serum once with ethanol : chloroform $(3: \mathrm{I})$ and twice with ethanol:ether $(3: I)$ and the phospholipid phosphorus and the total lipids were measured in the combined extracts as described above. The method of serum protein fractionation was the same as that used in a previous study (Wikramanayake, de Silva, Fernando \& Jayawickrema, 196r).

\section{Statistical analyses}

The significance of the changes in liver weight, total lipids, total cholesterol, total phospholipid phosphorus and the triglycerides with changes in carbohydrate intake was determined by the analysis of variance technique (Snedecor, 1961).

\section{RESULTS}

Table 2 summarizes the results of the first experiment. With the exception of one rat, the livers of all the animals on the protein-deficient diets showed some pathological change. Three livers showed a definite fatty change, the distribution of fat being mainly centrilobular, with a few fat globules distributed more diffusely throughout the liver lobule. In one, the fat distribution was uniform and diffuse. In the other livers the cells were swollen owing to either a hydropic degeneration or an early fatty change. There was a wide variation in the water content of tissues between individual rats, but the mean amount of water in carcass, liver and muscle decreased with increase in protein intake.

The variation in liver weight and in the lipid content of the livers with changes in energy level of the diet at different protein intakes in the second experiment is illustrated in Table 3 .

At each energy level the wet weight of the livers of rats fed on a high-protein diet 
was significantly greater than that of animals fed on the protein-free or the lowprotein diets $(P<0.001)$. Addition of glucose produced a more significant increase in the liver weight of the animals on the high-protein diet $(P<0.001)$ than in the animals on the other two diets $(0.01<P<0.05)$.

On the protein-deficient diets increasing the energy intake significantly increased the triglyceride content of the liver $(P<0.001)$. The decrease in triglyceride produced by increasing the protein content of the diet from o to $5 \%$ was not significant. On the other hand, there was a significant fall in the triglyceride content of the liver, at each energy level, when an adequate amount of protein was given $(P<0.00 \mathrm{I})$.

Table 2. Changes in histological appearance of the liver and in the water content of liver, muscle and carcass of rats caused by alterations in energy intake at different levels of protein intake

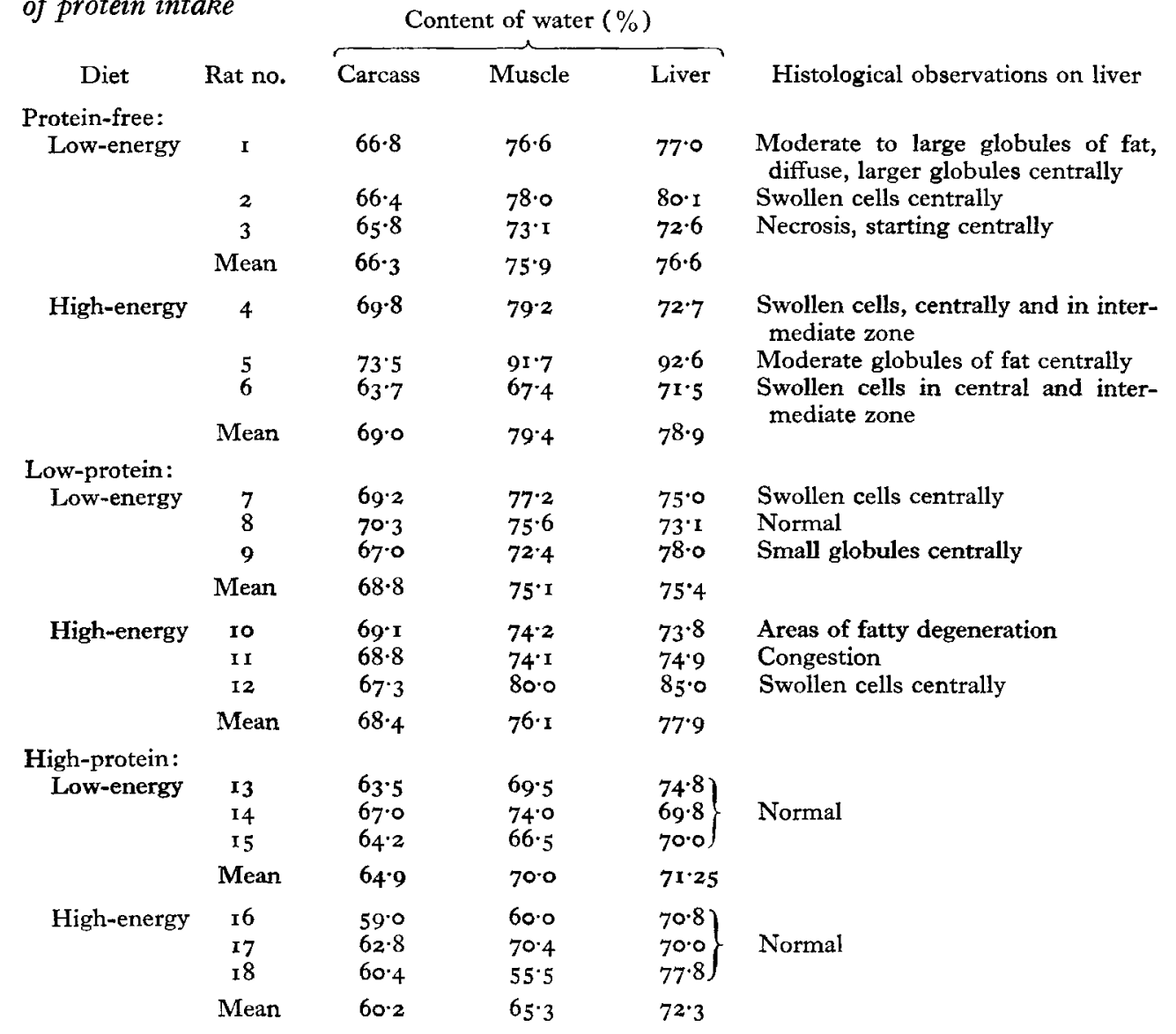

The liver cholesterol of animals on the high-protein diet was significantly greater than that of animals on the two protein-deficient diets at each energy level $(P<0.001)$. At each protein level additional glucose produced a highly significant increase in the liver cholesterol $(P<0.001)$.

Although the increase in liver phospholipid with increase in carbohydrate intake 
was slight on the protein-free diet, the change was highly significant on the highprotein $(P<0.001)$ and on the low-protein diets $(0.001<P<0.01)$.

Table 4 shows the effect of increasing the carbohydrate intake on the proteins and lipids of pooled serum of the animals in each group. Animals fed on adequate amounts of protein had about three times as much lipid in the serum as those on proteindeficient diets. The total protein content of the serum decreased with decrease in the protein content of the diet, the decrease being slightly greater with addition of carbohydrate at each protein level. The different protein fractions showed a similar decrease, the fall being less marked in the $\alpha$-globulin fractions.

Table 3. Effect of changes in energy intake (carbohydrate), at different levels of protein intake, on body-weight, liver weight and liver lipids of rats

(Mean values with their standard errors for groups of five rats)

\begin{tabular}{|c|c|c|c|c|c|c|c|}
\hline Diet & $\begin{array}{c}\text { Daily } \\
\text { energy } \\
\text { intake } \\
\left(\mathrm{kcal} / \mathrm{m}^{2}\right)\end{array}$ & $\begin{array}{c}\text { Change } \\
\text { in } \\
\text { body- } \\
\text { weight } \\
\text { (g) }\end{array}$ & $\begin{array}{c}\text { Liver } \\
\text { weight } \\
\text { (g) }\end{array}$ & $\begin{array}{l}\text { Total } \\
\text { liver } \\
\text { lipids } \\
\text { (mg) }\end{array}$ & $\begin{array}{c}\text { Total } \\
\text { liver } \\
\text { cholesterol } \\
\text { (mg) }\end{array}$ & $\begin{array}{l}\text { Total } \\
\text { liver } \\
\text { phospho- } \\
\text { lipid } \\
\text { (mg) }\end{array}$ & $\begin{array}{l}\text { Total } \\
\text { liver } \\
\text { trigly- } \\
\text { ceride } \\
\text { (mg) }\end{array}$ \\
\hline ein-free & $\begin{array}{r}872 \\
1810\end{array}$ & $\begin{array}{l}-5^{8} \pm 2 \cdot 50 \\
-51 \pm 2 \cdot 00\end{array}$ & $\begin{array}{l}3.4 \pm 0.19 \\
3.9 \pm 0.17\end{array}$ & & & $\begin{array}{l}4.67 \pm 0.22 \\
4.99 \pm 0.18\end{array}$ & $\begin{array}{l}220 \pm 18.62 \\
562 \pm 7.01\end{array}$ \\
\hline & $\begin{array}{r}883 \\
1825\end{array}$ & $\begin{array}{l}-58 \pm 0.84 \\
-46 \pm 1 \cdot 92\end{array}$ & $\begin{array}{l}3.5 \pm 0.09 \\
3.8 \pm 0.12\end{array}$ & $\begin{array}{l}309 \pm 10 \cdot 70 \\
605 \pm 36 \cdot 20\end{array}$ & $\begin{array}{l}12.4 \pm 0.70 \\
18.3 \pm 0.64\end{array}$ & $\begin{array}{l}4.98 \pm 0.25 \\
6 \cdot 17 \pm 0.30\end{array}$ & $\begin{array}{l}172 \pm 12 \cdot 80 \\
437 \pm 36.53\end{array}$ \\
\hline & $\begin{array}{r}883 \\
1825\end{array}$ & $\begin{array}{l}-15 \pm I \cdot 39 \\
+27 \pm 1 \cdot 31\end{array}$ & $\begin{array}{l}5 \cdot 0 \pm 0.35 \\
6 \cdot 3 \pm 0.28\end{array}$ & $\begin{array}{l}252 \pm 16 \cdot 40 \\
306 \pm 11 \cdot 10\end{array}$ & $\begin{array}{l}16 \cdot 1 \pm 0.85 \\
22 \cdot 1 \pm 0.50\end{array}$ & $\begin{array}{l}5 \cdot 76 \pm 0.40 \\
7 \cdot 67 \pm 0.38\end{array}$ & $\begin{array}{l}92 \pm 7.32 \\
91 \pm 5.77\end{array}$ \\
\hline
\end{tabular}

Table 4. Effect of changes in energy intake (carbohydrate), at different levels of protein intake, on serum proteins and lipids

\begin{tabular}{|c|c|c|c|c|c|c|c|c|c|}
\hline & \multicolumn{7}{|c|}{ (Serum from each group of five rats has been pooled for analysis) } & \multirow{2}{*}{$\begin{array}{l}\text { Total } \\
\text { choles- } \\
\text { terol }\end{array}$} & \multirow[b]{2}{*}{$\begin{array}{l}\text { Lipid } \\
\text { phos- } \\
\text { phorus }\end{array}$} \\
\hline & $\begin{array}{c}\text { Total } \\
\text { protein }\end{array}$ & Albumin & $\alpha_{1}$-globulins & $\alpha_{2}$-globulins & $\beta$-globulins & $\gamma$-globulins & $\begin{array}{l}\text { Total } \\
\text { lipids }\end{array}$ & & \\
\hline Diet & \multicolumn{6}{|c|}{$(\mathrm{g} / 100 \mathrm{ml})$} & \multicolumn{3}{|c|}{$(\mathrm{mg} / 100 \mathrm{ml})$} \\
\hline $\begin{array}{l}\text { Protein-free: } \\
\text { Low-energy } \\
\text { High-energy }\end{array}$ & $\begin{array}{l}3.87 \\
3.88\end{array}$ & $\begin{array}{l}x \cdot 65 \\
x \cdot 67\end{array}$ & $\begin{array}{l}0.75 \\
0.74\end{array}$ & $\begin{array}{l}0.30 \\
0.27\end{array}$ & $\begin{array}{l}0.52 \\
0.51\end{array}$ & $\begin{array}{l}0.65 \\
0.69\end{array}$ & $\begin{array}{l}\text { IOI } \\
\text { I21 }\end{array}$ & $\begin{array}{l}28 \\
32\end{array}$ & $\begin{array}{l}2 \cdot 3 \\
2 \cdot 9\end{array}$ \\
\hline $\begin{array}{l}\text { Low-protein: } \\
\text { Low-energy } \\
\text { High-energy }\end{array}$ & $\begin{array}{l}3.59 \\
4.01\end{array}$ & $\begin{array}{l}I \cdot 70 \\
I \cdot 82\end{array}$ & $\begin{array}{l}0.72 \\
0.78\end{array}$ & $\begin{array}{l}0.28 \\
0.29\end{array}$ & $\begin{array}{l}0.39 \\
0.54\end{array}$ & $\begin{array}{l}0.50 \\
0.58\end{array}$ & $\begin{array}{l}118 \\
129\end{array}$ & $\begin{array}{l}34 \\
42\end{array}$ & $\begin{array}{l}3.0 \\
3.7\end{array}$ \\
\hline $\begin{array}{l}\text { High-protein } \\
\text { Low-energy } \\
\text { High-energy }\end{array}$ & $\begin{array}{l}5 \cdot 67 \\
5 \cdot 82\end{array}$ & $\begin{array}{l}2 \cdot 35 \\
2 \cdot 32\end{array}$ & $\begin{array}{l}0.95 \\
0.94\end{array}$ & $\begin{array}{l}0.45 \\
0.48\end{array}$ & $\begin{array}{l}0.89 \\
0.99\end{array}$ & $\begin{array}{l}I \cdot 03 \\
I .09\end{array}$ & $\begin{array}{l}329 \\
358\end{array}$ & $\begin{array}{l}75 \\
86\end{array}$ & $\begin{array}{l}5 \cdot 5 \\
6 \cdot 2\end{array}$ \\
\hline
\end{tabular}

\section{DISCUSSION}

As observed by previous authors (Tucker \& Eckstein, 1937; Litwack, Hankes \& Elvehjem, 1952), the livers of rats fed on low-protein diets were fatty, owing mainly to the accumulation of triglycerides. As in the experiments of Macdonald (1962) on rabbits, the increase in liver lipid was more marked when the carbohydrate intake was increased. When the protein intake was adequate addition of carbohydrate to the diet did not increase the total amount of liver triglyceride.

Platt, Halder \& Doell ( 1962 ) obtained similar results with rats fed on diets containing 
0,2 or $5 \%$ protein as casein for a period of 6 days only. The deficient diets were given at the rate of $\mathrm{I} \cdot 3 \mathrm{~g} / \mathrm{I}$ o g body-weight daily, at which level the livers were found to be heavily infiltrated with fat. Animals fed on the same diet at $0.7 \mathrm{~g} / \mathrm{log}$ body-weight daily for 6 days did not show any histological change. In the experiments reported here animals fed at a low energy level ate daily about $0.4 \mathrm{~g} / \mathrm{I} 0 \mathrm{~g}$ body-weight and those at the higher energy level about $0.82 \mathrm{~g} / \mathrm{rog}$ body-weight, the diet being continued for 7 weeks. At both energy levels triglycerides accumulated in the liver, the amount of triglyceride being greater at the higher energy level. An increase of fat in the liver can, therefore, be brought about acutely by force-feeding with a large excess of a proteinfree diet for a short time, or by a smaller quantity of such a diet given for a much longer period of time. An adequate amount of protein in the diet prevents a fatty change.

In these experiments the food was available to the animals during $17 \mathrm{~h}$ of the day and only the morning meal was given by stomach tube along with any food remaining uneaten. It is unlikely, therefore, that the fatty livers were caused by forced feeding (cf. Cohn \& Joseph, r959; Fábry, Petrásek, Braun, Bednárek, Horáková \& Konopásek, i962). Moreover, the animals on the protein-deficient diets were grossly emaciated and their body fat was greatly reduced, unlike the animals force-fed by Cohn \& Joseph (I959).

Two distinct lipotrophic effects of proteins are known: (I) the choline-sparing effect of methionine, and (2) the effect of other amino acids, such as threonine (Tucker \& Eckstein, 1937; Best, Hartroft, Lucas \& Ridout, r955; Harper, r958). The fatty livers of the rats used in the study now presented were not likely to be due to a dietary deficiency of choline since the diets used provided $40 \mathrm{mg}$ choline/rat daily (Brown \& Sturtevant, I949). The accumulation of fat in the liver was accompanied by a fall in the lipid content of the serum, indicating a failure of the 'triglyceride secretory' mechanism of the liver (Recknagel \& Litteria, I960). This failure could be due to a decrease in the synthesis in the liver of cholesterol, phospholipid and lipoprotein or in lipoprotein alone (Olson, 1962). Results shown in Table 3, as well as those reported earlier (Wikramanayake et al. 1953), suggest the possibility that a protein-deficient diet may eventually reduce the concentration of some essential component (other than choline) in phospholipid synthesis to such an extent that it becomes the factor limiting the rate of synthesis.

Recent work on fatty livers, however, suggests another mechanism. Carbon tetrachloride (Seakins \& Robinson, 1963 ), the methionine antagonist, ethionine(Robinson \& Harris, I961), and the antibiotic, puromycin (Robinson \& Seakins, 1962) produce fatty livers and a reduction in plasma lipids under conditions in which the incorporation of amino acids into the proteins of the liver and the protein moiety of the plasma lipoproteins synthesized in the liver, is reduced. A protein-deficient diet could likewise result in a rate of synthesis of lipoproteins inadequate for efficient functioning of the 'triglyceride secretory' mechanism of the liver. A high-carbohydrate diet could result in increased insulin secretion which will bring about a deposition of amino acids in muscle (Munro, I956; Munro, Black \& Thomson, 1959). If the diet is also protein-deficient the supply of amino acids available to other tissues would be curtailed so that protein synthesis by tissues such as the liver is diminished. 
Addition of carbohydrate to a low-protein diet has been shown to decrease the amount of protein in the liver (Munro \& Naismith, I953). Further, a high calorie intake superimposed on a deficient protein intake has been shown to act as an added stress in the depletion of RNA and protein in the liver, muscle and other tissues, the reduction in free essential amino acids being greatest in the liver (Allison \& Wannemacher, 1964). A similar effect of high-carbohydrate diets in the production of fatty livers has been noted by Sidransky \& Clark (1961) in their study of acute amino acid deficiency. A deficiency of essential fatty acids is unlikely to have affected the utilization of dietary proteins by the animals used in the experiments presented here (Naismith, I962) because fat provided about $25 \%$ of the calories (at the lower energy level) and about $30 \mathrm{mg}$ linoleic acid (Deuel, I95I).

The distribution of fat in the liver differed from that found in kwashiorkor (Best et al. I955; Scrimshaw, Behar, Arroyave, Viteri \& Tejeda, I956), and in acute amino acid deficiency (Sidransky \& Clark, 196r). The picture is complicated by the fact that, towards the end of Expt I, many of the animals on the deficient diets did not eat all the food given to them. Fat is known to accumulate in the liver during starvation (Feigenbaum, Fisher \& Weiss, 1962). In a similar experiment on rats on a proteindeficient diet given ad lib., Ramalingaswami, Sriramachari \& Patwardhan (1958) found a mild fatty change with no clear-cut zonal distribution, the liver injury being much less evident in animals fed on a low-calorie diet. When the diet was deficient in both protein and choline, the fatty change was more marked and the distribution of fat was irregular in the ist month of deficiency, becoming more severe around the portal tracts in subsequent weeks. At the end of 3 months the distribution was periportal in four out of six rats, being centrilobular in the remainder. Therefore the distribution of fat appears to be dependent on the length of time the rats have been maintained on a deficient diet.

We are most grateful to Dr G. E. Tennakoon and Dr R. Panabokke of the Department of Pathology for reporting on the histology of the livers, and to Dr P. L. G. de Silva of the Department of Animal Husbandry for helpful discussion on statistical treatment. The assistance of Mr George Hoover in the care and management of the animals is gratefully acknowledged.

\section{REFERENCES}

Allen, R. J. L. (1940). Biochem. F. 34, 858 .

Allison, J. B. \& Wannemacher, R. W. Jr (I964). Int. Congr. Nutr. vi. Edinburgh, p. 301 .

Best, C. H., Hartroft, W. S., Lucas, C. C. \& Ridout, J. H. (1955). Br. med. F. i, I 439.

Brown, R. A. \& Sturtevant, M. (1949). Vitams Horm. 7, I7 I.

Cohn, C. \& Joseph, D. (1959). Am. F. Physiol. r96, 965.

Deuel, H. J. Jr (I95I). The Lipids. Vol. I, p. I95. London: Interscience Publishers Ltd.

Fábry, P., Petrásek, R., Braun, T., Bednárek, M., Horáková, E. \& Konopásek, E. (I962). Experientia I8, 555 .

Feigenbaum, A. S., Fisher, H. \& Weiss, H. S. (1962). Am. Y. clin. Nutr. 11, 312.

Harper, A. E. (1958). Am. F. clin. Nutr. 6, 242.

Heard, C. R. C., Platt, B. S. \& Stewart, R. J. C. (1958). Proc. Nutr. Soc. 17, xli.

Henly, A. A. (1957). Analyst, Lond. 82, 286.

Lee, M. O. (1929). Am. F. Physiol. 89, 24.

Litwack, G., Hankes, L. V. \& Elvehjem, C. A. (1952). Proc. Soc. exp. Biol. Med. 8I, 441. 
Macdonald, I. (1962). F. Physiol., Lond. I62, 334.

Munro, H. N. (1949). \%. Nutr. 39, 375.

Munro, H. N. (1956). Scot. med. F. i, 285.

Munro, H. N., Black, J. G. \& Thomson, W. S. T. (1959). Br. J. Nutr. 13, 475.

Munro, H. N. \& Naismith, D. J. (r953). Biochem. F. 54, I9r.

Munro, H. N., Naismith, D. J. \& Wikramanayake, T. W. (1953). Biochem. F. 54, 198.

Munro, H. N. \& Wikramanayake, T. W. (1954). F. Nutr. 52, 99.

Naismith, D. J. (1962). $\mathscr{F}$. Nutr. 77, 381 .

Olson, R. E. (1962). Proc. Nutr. Soc. 21, 135.

Platt, B. S., Halder, K. \& Doell, B. H. (I962). Proc. Nutr. Soc. 21, vi.

Ramalingaswami, V., Sriramachari, S. \& Patwardhan, V. N. (1958). Indian Y. Path. Bact. r, 104.

Recknagel, R. O. \& Litteria, M. (1960). Am. F. Path. 36, 521.

Robinson, D. S. \& Harris, P. M. (196r). Biochem. 7. 80, 36r.

Robinson, D. S. \& Seakins, A. (1962). Biochim. biophys. Acta 62, 163.

Scrimshaw, N. S. \& Behar, M. (1959). Fedn Proc. Fedn Am. Socs exp. Biol. 18, 82.

Scrimshaw, N. S., Behar, M., Arroyave, G., Viteri, F. \& Tejeda, C. (1956). Fedn Proc. Fedn Am. Socs exp. Biol. 15, 977 .

Seakins, A. \& Robinson, D. S. (1963). Biochem. F. 86, 401 .

Sidransky, H. \& Clark, S. (196r). Archs. Path. 72, ro6.

Snedecor, G. W. (196r). Statistical Methods. Bombay: Allied Pacific Private Ltd.

Tucker, H. F. \& Eckstein, H. C. (1937). F. biol. Chem. 121, 479.

Wikramanayake, T. W. (1964). Proc. Ceylon Ass. Advant. Sci. p. 6.

Wikramanayake, T. W., de Silva, C. C., Fernando, P. V. D. \& Jayawickrema, L. (196I). Am. F. clin. Nutr. 9, 625 .

Wikramanayake, T. W., Munro, H. N., Naismith, D. J. \& Hutchinson, W. C. (1953). Biochem. F. 55, 649. 